\title{
SPOLM2O19
}

XIX SIMPÓSIO DE PESQUISA OPERACIONAL E LOGISTICA DA MARINHA RIO DE JANEIRO, RJ, BRASIL - 06 A 08 DE NOVEMBRO DE 2019

\section{AN EMPIRICAL EXAMINATION OF THE IMPACT OF SUPPLY CHAIN RISKS UPON ORGANIZATIONAL OPERATIONAL PERFORMANCE: AN ANALYSIS AT BRAZILIAN INDUSTRIES USING A STRUCTURAL EQUATION MODELING APPROACH}

\author{
${ }^{1}$ Thiago Fernandes Lima, ${ }^{2}$ Bouchaib Bahli, ${ }^{3}$ Samuel de Jesus Monteiro Barros, ${ }^{4}$ Jorge \\ Luciano Gil Kolotelo, ${ }^{5}$ Nathan Peixoto Oliveira \\ ${ }^{1}$ Marinha do Brasil (fernandes.lima@marinha.mil.br), ${ }^{2}$ Ryerson University \\ (bahli@ryerson.ca), ${ }^{3}$ IBMEC (samuel.barros@,ibmec.edu.br), ${ }^{4}$ Université de Bordeaux \\ (kolotelo@gmail.com), ${ }^{5}$ Université de Bordeaux (nathanpeixot@yahoo.com.br)
}

\begin{abstract}
The present work intends to contribute to the Supply Chain field and Contingency Theory by promoting a quantitative evaluation, in the context of Brazilian Industry, about the interaction between different types of Supply Chain Risks and Operational Performance, which are all core elements of contingency models. For that purpose, the following main research question was drawn: Does Supply Chain Risks influence negatively Operational Performance in the context of Brazilian Industries? The articles reviewed were retrieved from Scopus database. The keywords used to search for previous articles were Supply Chain Risks and Operational Performance. Three different hypotheses were developed, and test based on the proposed main question. The data used in this study stem from empirical observations through surveys. The results were obtained with the application of Structural Equation Modeling (SEM), using partial least squares (PLS) approach, with the support of the SmartPLS 3.0 software.
\end{abstract}

Keywords: Operational Performance; Supply Chain Risks; Structural Equation Modeling.

\section{RESUMO}

O presente trabalho pretende contribuir para o campo Supply Chain e Contingency Theory, promovendo uma avaliação quantitativa, no contexto da indústria brasileira, sobre a interação entre os diferentes tipos de Riscos da Cadeia de Suprimentos e o Desempenho Operacional, que são todos os elementos centrais dos modelos de contingência. Para tanto, foi formulada a seguinte questão principal de pesquisa: Os riscos da cadeia de suprimentos influenciam negativamente o desempenho operacional no contexto das indústrias brasileiras? Os artigos revisados foram recuperados do banco de dados Scopus. As palavras-chave usadas para pesquisar artigos anteriores foram: Riscos da Cadeia de Suprimentos e Desempenho Operacional. Três hipóteses diferentes foram desenvolvidas e testadas com base na questão principal proposta. Os dados utilizados neste estudo derivam de observações empíricas através de pesquisas. Os resultados foram obtidos com a aplicação da Modelagem de Equações Estruturais (MEE), utilizando a abordagem de mínimos quadrados parciais (PLS), com o apoio do software SmartPLS 3.0.

Palavras-chave: Desempenho Operacional; Riscos da Cadeia de Suprimentos; Modelagem de Equações Estruturais. 


\section{Como Citar:}

LIMA, Thiago Fernandes et al. An empirical examination of the impact of supply chain risks upon operational performance: an analysis at Brazilian industries using a structural equation modeling approach. In: SIMPÓSIO DE PESQUISA OPERACIONAL E LOGÍSTICA DA MARINHA, 19., 2019, Rio de Janeiro, RJ. Anais [...]. Rio de Janeiro: Centro de Análises de Sistemas Navais, 2019.

\section{INTRODUCTION}

Supply chain management (SCM) has become a competitive strategy for all types of organizations. The global market value of the logistic and supply chain related sector was forecasted to grow around 29.3\% between 2016 and 2021 after reaching the business value of \$805 billion in 2016 (ALORA; BARUA, 2019).

So far, little attention has been paid to the links between risks and organizational operational performance in the context of Supply Chain Management (ZHAO et al, 2013). Zsisidin et al., (2005) contends that since companies can no longer afford to focus on local markets and consequently are forced to realize the potential of global markets in terms of suppliers as well as customers, this phenomenon results in a highly complex supply chain.

As a consequence of globalization, high interconnectedness between companies and close relationships within complex networks, supply chains have become more vulnerable for disturbances (ZSISIDIN et al., 2000). According to Jutnner, Christopher and Peck (2004) vulnerability can be defined as an exposure to serious disturbance, arising from risks within the supply chain as well as risks external to the supply chain.

Then, in such a volatile environment, successful supply chain management, and consequently organizational operational performance, tends to be influenced by the level of risk exposure derived from its internal and external environment. Based on such assumption, the application of Contingency Theory may support further investigations, since it underscores that an organization's operational performance is contingent on the fit between its structure, processes and environment (LAWRENCE; LORSCH, 1967).

As globalization have pushed companies into complex and uncertain Supply Networks, different schollars like El Hiri, En-Nadi(2018), Chafi, Jajja, Chatha, Farooq 2018), Zhao, Huo, Sun, and Zhao (2013), Chen (2018). have explored such movement in order to expand their knowledge and better explain the relationship between operational performance and supply chain risks but none of them, was solely focused upon Brazilian Industries particular context.

In this movement, Sweeney et al. (2015) have emphasized the importance of perspective and context in the field of Supply Chain Management research. Other schollars like Jin et al. (2013) encourage the need of research in developing countries to explore the infrastructural, political and the cultural issues that may affect Supply Chains considering its global nature.

It is also important to emphasize that according to different researchers there are important opportunities for future research in the field. Zhao et al. (2013), for instance, who studied the impact of supply delivery risk and demand variability on supply chain integration and company operational performance, contends that despite the fact that their study contributes to both the literature and practice, since Supply Chain Risk is a relatively new concept, its measurement is still at an explorative stage, then further research is required.

Then, the present work intends to sum up to the Supply Chain and Contingency Theories promoting an evaluation, in the context of Brazilian Industry, about the interaction between uncertainty (understood in this work as Supply Chain risks) and organizational Operational Performance, which are all core elements of contingency models, as defined by Pennings (1975). For that purpose, the following main research question has been drawn: 
Does Supply Chain Risks influence negatively Operational Performance in the context of Brazilian Industries?

A structural equation model will be draw from previous literature, developed and tested to assess the relationships between the following latent variable: Supply Chain Risks (represented here by the Supply Side Risks, Manufacturing Side Risks and Customer Side Risks) and Operational Performance.

In addition to section 1, under which the introduction and the main objective of the study were developed, the present paper is organized in five more sections, as follows:

- section 2: explore a theoretical background about Risks, Supply Chain Risks, as well as about Organizational Operational Performance.

- section 3: deals with the presentation of conceptual model and the research methodology to be applied

- section 4: analysis and results

- section 5: develop the conclusion

\section{LITERATURE REVIEW}

The articles reviewed were retrieved from Scopus database. The keywords used to search for previous articles were "Supply Chain Risks" and "Operational Performance". The bibliometric process Proknow-C (ENSSLIN et al.,2010) was used to select approximately 51 articles from a sample exceeding 2,000 articles, from those 36 were used as references in the present study.

\subsection{CONTINGENCY THEORY}

The General Contingency Theory of Management is grounded upon the view of an organization as a System where the goals and objectives are defined in terms of relevant environmental and resource constrains (LUTHANS; STEWART, 1977).

The Contingency Theory will guide the examination of the relationship between Supply Chain Risk and Organizational Operational Performance and since its theoretical is anchored upon investigating relationships between environmental, management and performance variables.

Based on the contingency model of the organization, system performance is a function of the interaction of system variable set. In the light of such theory, there are three primary system variables: environment, resources and management. (LUTHANS; STEWART, 1977).

Environment, for instance, encompasses contextual internal and external aspects like culture, socio-politic aspects, technology, legal systems, politics, economy, technology as well as customers, suppliers and competitors influences. Environmental variables are treated as independent variables in the contingency function (LUTHANS; STEWART, 1977).

Resource variables can be classified as human and non-human. Human resource variables include both demographic characteristics such as number, skills, knowledge, size, race and age, and behavioral characteristics including individual and social behavior and such attendant concepts as needs, attitudes, values, perceptions, expectations, goals, group dynamics and conflict. Non-human resource variables include such elements as raw materials, plant, equipment, capital and product or services. (LUTHANS; STEWART, 1977).

Management variables are those concepts and techniques expressed in policies, practices and procedures used by the manager to operate on available resource variables in defining and accomplishing system objectives. (LUTHANS; STEWART, 1977).

Then, using Contingency Theory as theoretical pillar, supply chain risks sources will be investigated in this research as critical contextual variables which derived from the primary 
systems that can be internal and external to supply chains, as suggested by following Wagner and Bode (2006) in their study.

The present paper suggests that risks from the various supply chain sources may influence negatively supply chain performance in the Brazilian business setting. If this assumption finds support statistically then the call for an organizational adaptation towards mitigating supply chain risk is substantiated and aligned with the contingency theory.

\subsection{RISKS}

Knight (1921) defined risk as the probability of incurring a loss whereas Sitkin and Pablo (1992) contends that risk can be defined as the extent to which there is uncertainty about whether potentially significant and/ or disappointing outcomes of decisions will be realized. MacCrimmon and Wehrung (1986) identified three components of risk: the magnitude of loss, the chance of loss and the potential exposure to loss.

Historically, risk has been defined using the relationship between the range of possible negative outcomes (severity or impact) and the distribution of the corresponding probabilities for each outcome (RAO; GOLDSBY, 2009). Miller (1992) highlights that risks in business refer to unanticipated variation or negative variation may influence business performance such as revenues, costs, profit, market share;

How to understand risk has evolved over time. According to Purdy (2010) through ISO: Guide 73, risk can be defined as effect of uncertainty on objectives. The author highlights that the ISO 31000 definition of risk shifts emphasis from past preoccupations with the possibility of an event (something happens) to the possibility of an effect and, in particular, an effect on objectives. Thus, based on this new perspective, the word "risk" refers to positive consequences of uncertainty as well as negative ones.

Despite the emergence of positive consequence perspective, for the purpose of this study the latter notion of risk as purely negative is the one that corresponds best to supply chain business reality. This view is aligned with Harland et al. (2003), Wagner and Bode (2006), Hendricks and Singhal (2005), for instance.

\subsection{SUPPLY CHAIN RISKS}

Macdonald et al. (2018) contends that Supply chain risk is a topic that is at a critical developmental stage and due to the increasing importance of this topics both researchers and practitioners have been contributed to the identification of factors contributing to risk, the impact of risk and disruptions on performance.

The following statistics, based on articles retrieved from Scopus database, using of the keywords "supply chain risks" (SCR), show that interest about the subject has increased year after year, despite the reduction in 2015.

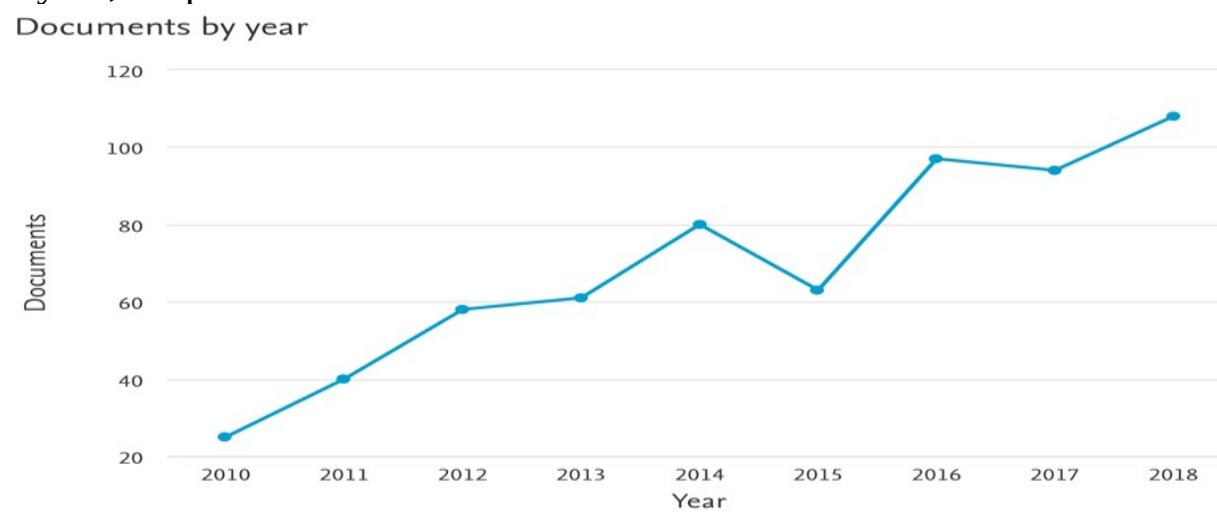

Figure 1 - SCR Published articles according to Scopus Database (December 2018) 
Despite the interest and efforts around the Supply Chain Risks area, there are still no common agreement concerning its definition and consequently different conceptual meanings can be found in the literature. For instance, Zsidisin, Panelli and Upton (2000) define Supply Chain Risks as the transpiration of significant and/or disappointing failures with inbound goods and services. According to Jüttner, Peck and Christopher (2003), Supply Chain Risks can be defined as the probability of disruption in any part of supply chain caused by internal or external sources that can impact objective of network negatively. Wagner and Bode (2006). considers risk as the negative deviation from the expected value of a certain performance measure, resulting in negative consequences for the focal firm.

For Mital, Giudice and Papa (2018), Supply Chain Risks are unplanned and unnatural events which are encountered frequently and can be categorized into internal to the firm, external to the firm but internal to the supply chain network, and external to the environment. Moreover, according to Jüttner, Peck and Christopher (2003), the supply chain risks comprise "any risks for the information, material and product flows from original supplier to the delivery of the final product for the end user"'

In terms of types of risks, there are several different interpretations in the literature, Rangel et al. (2015) summarized different types of risks, proposed its definition and associated it with each SCOR proposed process illustrated at table 1:

\begin{tabular}{|c|c|c|}
\hline Process & Risk & Definition \\
\hline \multirow[t]{5}{*}{ Plan } & Strategic & $\begin{array}{l}\text { Characterised by any event affecting the business strategy, such as a lack of strategic planning (both } \\
\text { organisational and SC-dependent) and the absence of a systemic perspective }\end{array}$ \\
\hline & Inertia & $\begin{array}{l}\text { Defined by the inability to remain in a competitive market, usually caused by the failure of the } \\
\text { organisation and/or chain to follow the market changes (e.g. technology, design, function, etc.) }\end{array}$ \\
\hline & Informational & $\begin{array}{l}\text { Results from failure in the information system due to deficient data feed systems or electronic systems or } \\
\text { the inability to receive, transfer and access information }\end{array}$ \\
\hline & Capacity & $\begin{array}{l}\text { Caused by effective production over- or underutilisation capacity, lack of flexibility to respond to changes } \\
\text { in demand or even the inability of some links (SC members) to plan, schedule and control production and } \\
\text { inventory management }\end{array}$ \\
\hline & Demand & $\begin{array}{l}\text { Occurs when there is poor demand forecasting (in terms of quantity and mix), seasonality, long lead } \\
\text { times, short product life cycles, small customer bases or information distortion due to promotions and } \\
\text { incentives. May result in the bullwhip effect }\end{array}$ \\
\hline \multirow[t]{3}{*}{ Source } & Supply & $\begin{array}{l}\text { Stems from inefficiencies in the supply chain process (e.g. an increase in the price of some inputs, } \\
\text { suppliers' lack of responsiveness, unavailability of inputs in terms of quantity and/or quality) and } \\
\text { problems in internal product flow }\end{array}$ \\
\hline & Financial & $\begin{array}{l}\text { Arises from cash flow problems (product pricing, delinquencies by debtors, non-payment) and changes in } \\
\text { the financial market (taxes, exchange rates, licences, etc.) }\end{array}$ \\
\hline & Relational & $\begin{array}{l}\text { Stems from the relationship among supply chain links (members), such as membersp lack of visibility, } \\
\text { opportunism, trust in information transfer, sub-par cooperation and interaction among members and } \\
\text { outsourcing (e.g. a supplier supplying the chain and its competitors or a supplier redesigning parts and } \\
\text { creating its own product) }\end{array}$ \\
\hline \multirow[t]{2}{*}{ Make } & Operational & $\begin{array}{l}\text { Results from situations preventing the focal company from performing its production activities, which } \\
\text { may be related to problems with production systems, internal policies, procedures, processes and people }\end{array}$ \\
\hline & Disruption & $\begin{array}{l}\text { Results from discontinuity in the materials flow in the production process (following suspension in } \\
\text { activities that add value to the customer), for example, arising from the reliance on a single source of } \\
\text { supplies and labour strikes }\end{array}$ \\
\hline Delivery & Customer & $\begin{array}{l}\text { Focuses on situations that modify customer choice, reducing the number of applications, e.g. product } \\
\text { obsolescence, product delivery, customer service (before, during and after the order request) and } \\
\text { confidence loss in the product or brand }\end{array}$ \\
\hline Return & Legal & $\begin{array}{l}\text { Begins with the inability of the organisation and/or the chain to comply with legal restrictions or further } \\
\text { exposure to litigation }\end{array}$ \\
\hline \multirow[t]{2}{*}{ Others } & Environmental & $\begin{array}{l}\text { Stems from events outside the chain, e.g. natural disasters and uncertainties in governmental (legislation, } \\
\text { regulatory), economic, technological and social policies }\end{array}$ \\
\hline & Culture & $\begin{array}{l}\text { Defined by the difference in business culture among the links (members) of the chain or differences in the } \\
\text { culture, language and people in the countries in which they are located }\end{array}$ \\
\hline
\end{tabular}

Table 1 - Risk Type and Definition - Rangel et al. (2015)

Other authors continue to research and suggesting risks types that may affect Supply Chain. For instance, Tang and Musa (2011) research identified Supply Chain Risks in areas like material, information and financial flows. Ho et all (2015) classified Supply Chain Risks along factors such as Demand, Manufacturing, Supply and Infrastructural.

Mital, Giudice and Papa (2018) also categorized potential supply chain risks as delays, disruptions, forecast inaccuracies, systems breakdowns, intellectual property breaches, procurement failures, inventory problems and capacity issues.

Rudolf and Spinler (2018) explored key risks in the supply chain of large-scale engineering and construction projects, considering the field of Supply Chain Management, 
their study contributes to the field defining a supply chain risk taxonomy for large scale project as shown in figure 2:
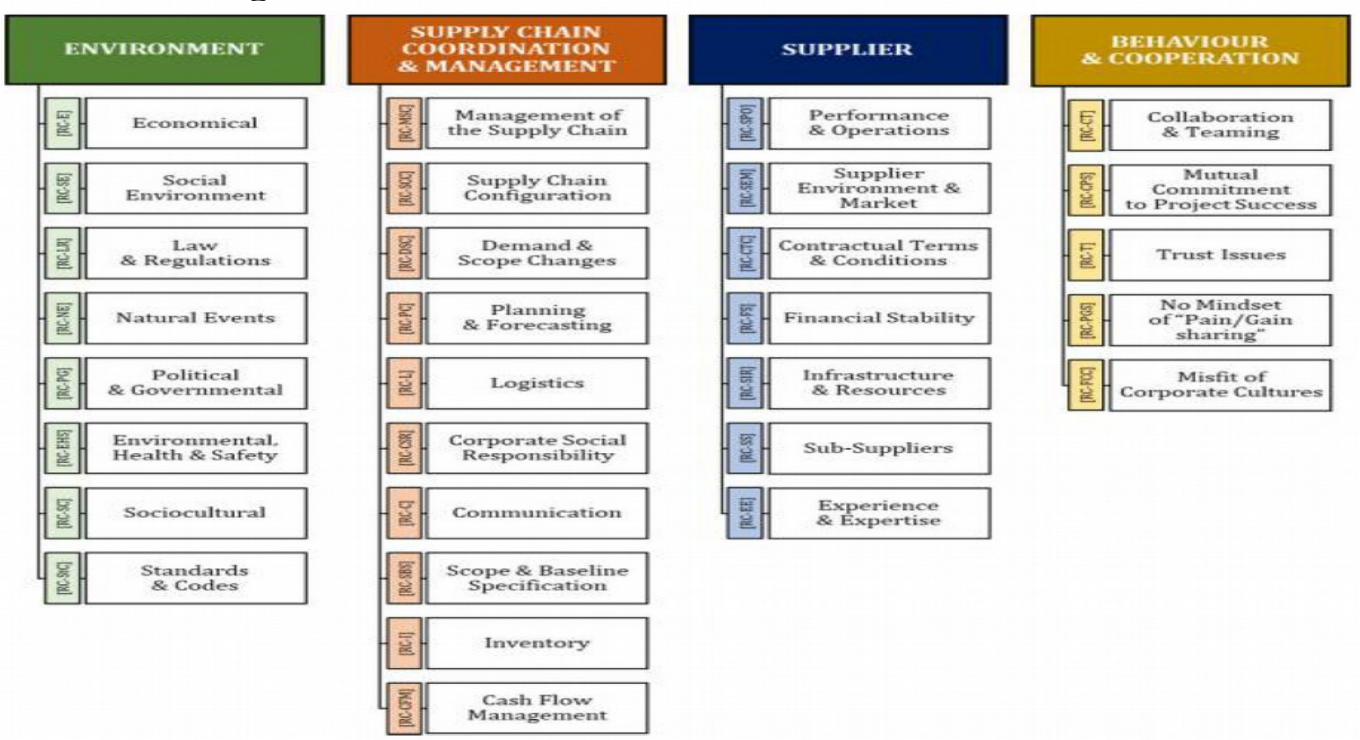

Figure 2 - Supply Chain Risk Taxonomy. Rudolf and Spinler (2018)

The diversity of risk categories illustrated about convey a lack of standardization in classifications and category types. The authors usually also diverge about the risk factors as well as the number of categories.

In terms of operationalization of measures to assess supply chain risks, Punniyamoorthy, M., Thamaraiselvan and Manikandan (2013), for instance, provide a reliable and accurate instrument to assess the different types of risk derived from supply chains, as shown in figure 3 . The authors suggested that the instrument developed may be used with modification and the higher order model could be used for prioritizing the risk constructs. The instrument may also be used to quantify the overall risk of the supply chain using an integrated risk measurement model.

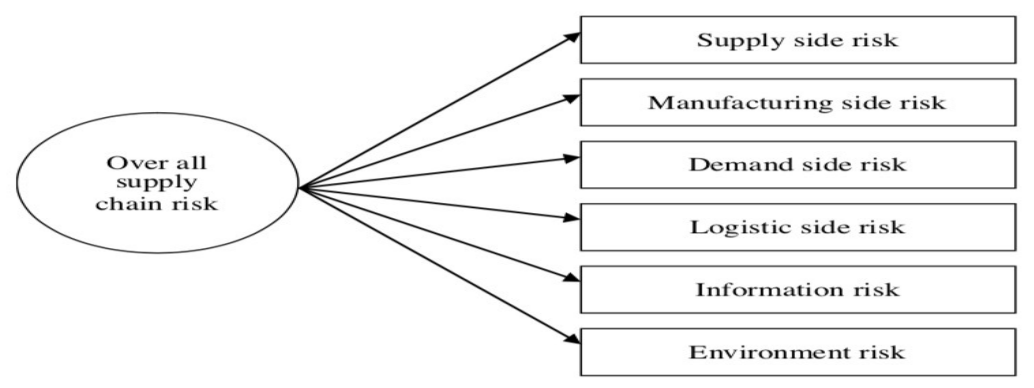

Figure 3 - Sources of Supply Chain Risks - Punniyamoorthy et al. (2013)

For the purpose this study, the following three risk sources, supplier, manufacturer and demand (customer) risks will be applied in the context of Brazilian Industry. The measurement items developed by Punniyamoorthy et al. (2013) will be utilized as reference of the research. Respondents were asked to rate a grade for each risk variable by considering to what extent your company / organization in recent years has had a negative impact because of the variable presented. Use the 5-point scale for "high occurrence" and 1 point when "not observed".

\subsection{OPERATIONAL PERFORMANCE}

As highlighted by Voss et al (1997) Operational performance encompasses the 
measurable aspects of the outcomes of an organization's processes and. Operational performance in turn affects business performance measures such as market share and customer satisfaction. Lu et al (2018) argues that Operational performance (OP) is a key enabler to the overall supply chain performance.

There are multiple measurements for operational performance such as order fulfilment, delivery as promised, delivery flexibility, flexibility to change output volume and flexibility to change product mix, forecasting accuracy, overall product quality, customer service level, responsiveness, operational efficiency and flexibility (HUO et al., 2014; BONGSUG et al., 2014; MEHMET et al., 2017; SHOU et al. 2018).

Performance criteria were decided by reviewing literature of the scholar above. The following measurement item were selected: delivery on time, order fulfilment; forecasting accuracy, lead time, service after sale, average inventory level, overall product quality and customer service level. Respondents were asked to check their opinion about their company relative performance in the market on a scale from: 1-Very Poor; 2- Below Average; 3Average; 4-Above Average and 5-Excellent.

\section{RESEARCH METHOD}

In order to process the collected data, a path diagram, available at figure 4, was built to show the relationship between the dependent and independent variables, including their related variables (KRISTENSEN; ESKILDSEN, 2010). The data were analyzed, and the results were obtained with the application of structural equation modeling (SEM) using partial least squares (PLS) with the support of the SmartPLS 3.0 software.

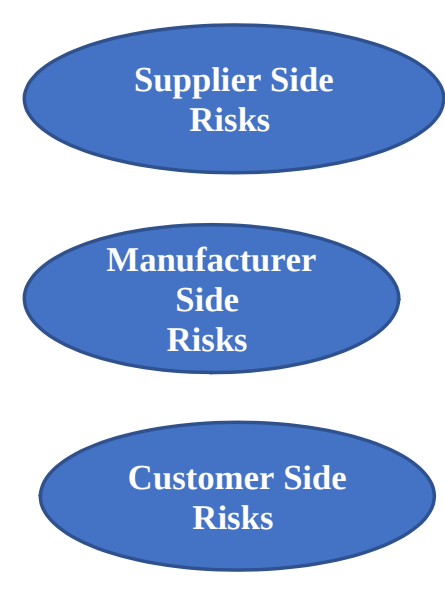

Figure 4 - Conceptual Model

This research was quantitative and based on an electronic survey. About 400 potential participants were contacted by particular messages through LinkedIn between February and April 2019. A total of 99 questionnaires were collected 38 were disregard due to the fact it was related to service sector, resulting in 61 useable responses. Thus, an effective return rate of $15 \%$ was obtained. Of the participants in the final research sample $100 \%$ were from the manufacturing sectors, from segments like automotive companies, chemical sector, electronics sector, oil and gas, and few other ones.

We proposed the research framework shown in Fig. 5. Survey studies are generally relational because they tend to be designed to empirically examine relationships among two or more constructs or variables (RUNGTUSANATHAM et al., 2003). Then the survey approach was selected in this work mainly because we tested the relationship between Supply Side Risks, Manufacturer Side Risks and Customer Side Risks with Operational Performance. 
The following main hypothesis were developed and test: H1:Supply Side Risks (SCRS) are negatively related to Operational Performance (Op Performance)? H2: Manufacturing Side Risks (SCMR) are negatively related to Op Performance? H3: Customer Side Risks (SCRD) are negatively related to Op Performance?

The survey questionnaire used included the measurement of ten different types of Supply Side Risks, seven different types of Manufacturing Side Risks, six different types of Demand side risk and eight different types of Operational Performance indicators.

As mentioned previously the selected supply chain risks indicators used in this study were developed and validated by Punniyamoorthy et al. (2013) in the Indian context while the Operational Performancwere based on the validated scale from Huo et al. (2014) and Bongsug et al. (2014). At table 2 the references for all the selected items in the research questionnaire are presented and in the Appendix A the measurement items are displayed.

\begin{tabular}{|c|c|c|c|c|c|}
\hline Variable Name & Reference: & $\begin{array}{c}\text { Role of } \\
\text { variable in } \\
\text { study }\end{array}$ & Scale & $\begin{array}{c}\text { Operational } \\
\text { definition }\end{array}$ & $\begin{array}{c}\text { Range } \\
\text { of } \\
\text { values }\end{array}$ \\
\hline $\begin{array}{c}\text { Supply Chain } \\
\text { Risk }\end{array}$ & $\begin{array}{c}\text { Punniyamoorthy et } \\
\text { al. (2013). }\end{array}$ & Independent & Interval/ratio & $\begin{array}{c}\text { Calculated by } \\
\text { averaging } \\
\text { questions of } \\
\text { survey } \\
\text { available at } \\
\text { Appendix A }\end{array}$ & $1-5$ \\
\hline $\begin{array}{c}\text { Organizational } \\
\text { performance }\end{array}$ & $\begin{array}{c}\text { Huo, et al. (2014). } \\
\text { Bongsug et al. } \\
(2014)\end{array}$ & Mehmet et al. \\
$(2017)$ & Dependent & Interval/ratio & $\begin{array}{c}\text { Calculated by } \\
\text { averaging } \\
\text { questions of } \\
\text { survey } \\
\text { available at } \\
\text { Appendix B }\end{array}$ & $1-5$ \\
\hline
\end{tabular}

Table 2 - Construct Sources

\section{ANALYSIS AND RESULTS}

As suggested by Wong (2013) and Hair Jr. et al (1998), the assessment of Partial Least Square - Structural Equation Model (PLS-SEM model), should covered the following topics: explanation of target endogenous variable variance; Inner model path coefficient sizes and significance; Outer model loadings and significance; Indicator reliability; Internal consistency reliability; Convergent validity and Discriminant validity; and Structural Path Significance in Bootstrapping.

In order to execute the assessment suggested above, the first step was to process the path diagram of the measurement model to determine if the obtained coefficients of the outer and inner model were significant, the initial results are shown in Fig. 5 as well as at tables 3 and 4 . We found that the constructs needed to be refined with a reduced number of variables mainly because some variables had Outer Loadings lower than 0.6 (see figure 5), as well as Average Variance Extracted (AVE) lower than 0.5, see table 3, both of which lower than the recommended level indicated by Latan and Ghozali (2012). Based on such assumptions the indicators MOP6, MOP7, SCRD 4, SCRD6, SCRS 5, SCRS 6, SCRS7 SCRS 9, SCRS 10 and SCRM1 e SCRM7 were excluded as recommended by Latan and Ghozali (2012). 


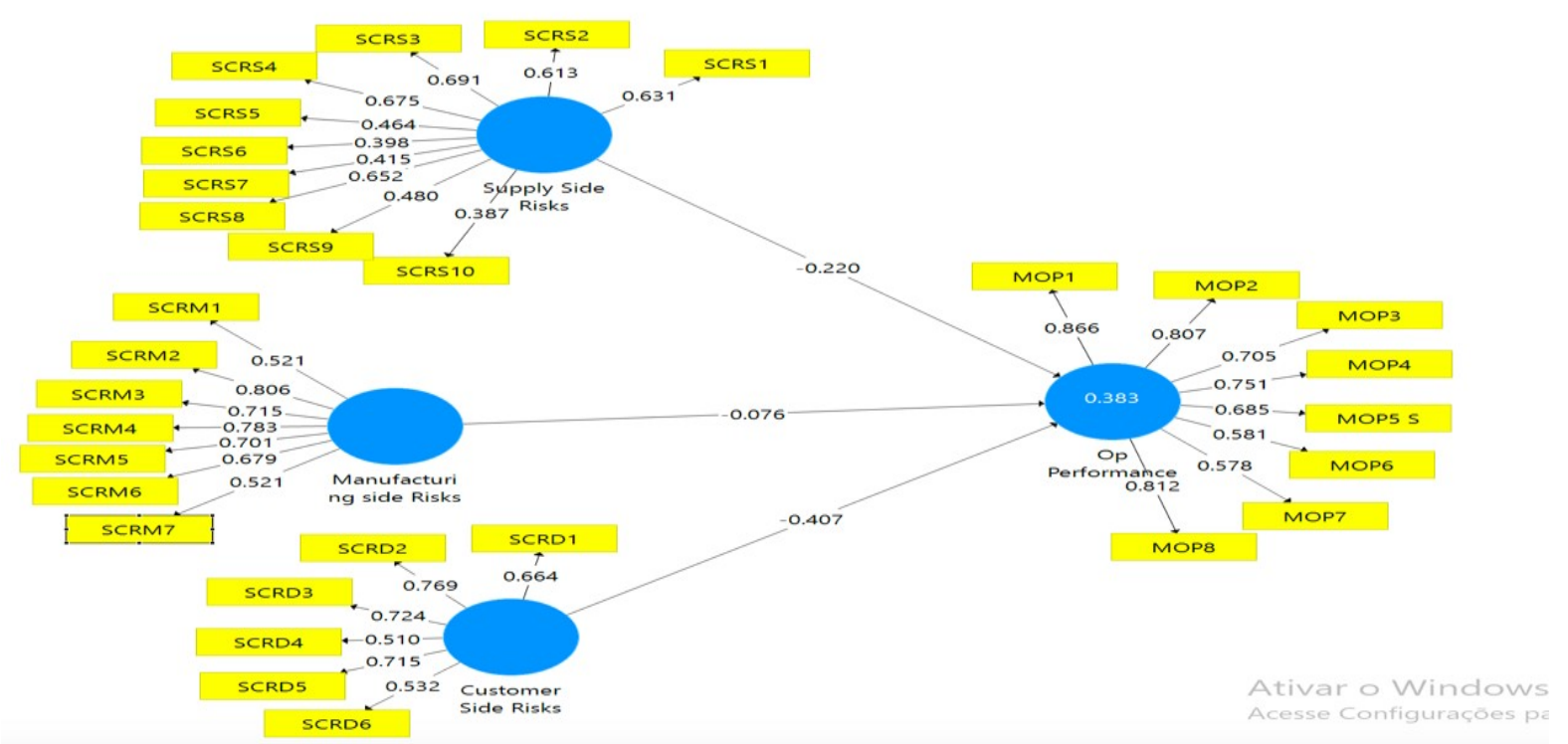

Figure 5- Initial Conceptual Model - (inner and outer model) before adjustments

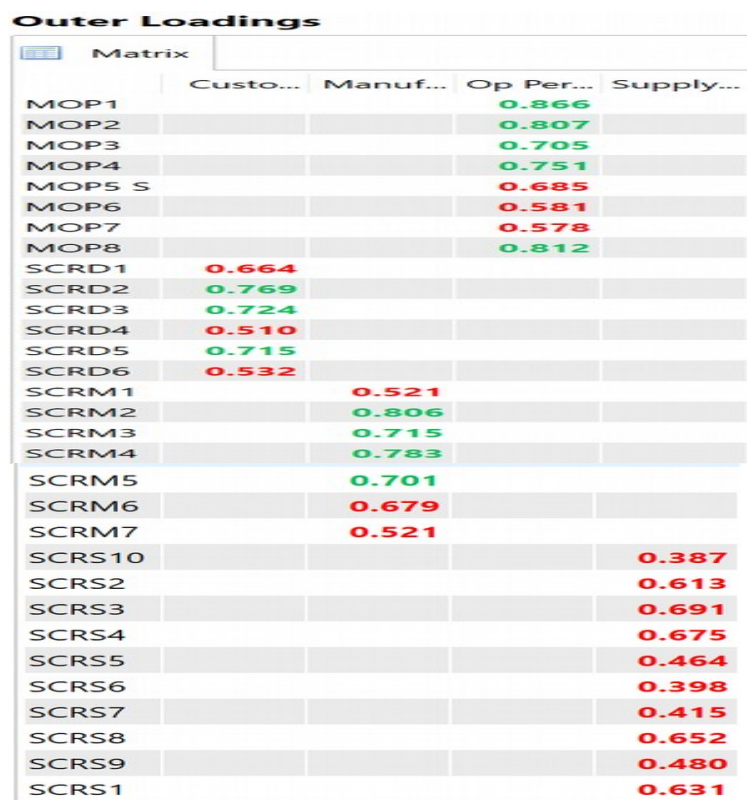

Table 3 - Outter Loadings - before adjustments

\begin{tabular}{|l|rrrr|}
\hline & Cronbach's Al... & rho_A & Composite Reliability & Average Varia... \\
\hline Customer Side Risks & 0.742 & 0.770 & 0.819 & 0.435 \\
\hline Manufacturing side Risks & 0.812 & 0.837 & 0.857 & 0.467 \\
\hline Op Performance & 0.871 & 0.887 & 0.900 & 0.533 \\
\hline Supply Side Risks & 0.746 & 0.730 & 0.808 & 0.306 \\
\hline
\end{tabular}

Table 4 - Quality Criteria - Inner model - before adjustments

After the adjustments stated above, all the first-order constructs were retested to check the Outer Loadings as well as the validity and reliability of the Inner model. Table 5 shows that the loading factors for all the indicators were now greater than 0.6 and Table 6 indicates that the values of Average Variance Extracted |(AVE) and Composite Reliability (CR), generated by each construct, were above 0.5 and 0.7 , respectively. Then, the convergent validity, internal consistency reliability, and discriminant validity showed improved statistical fit, as suggested by the literature (LATAN; GHOZALI, 2012). 


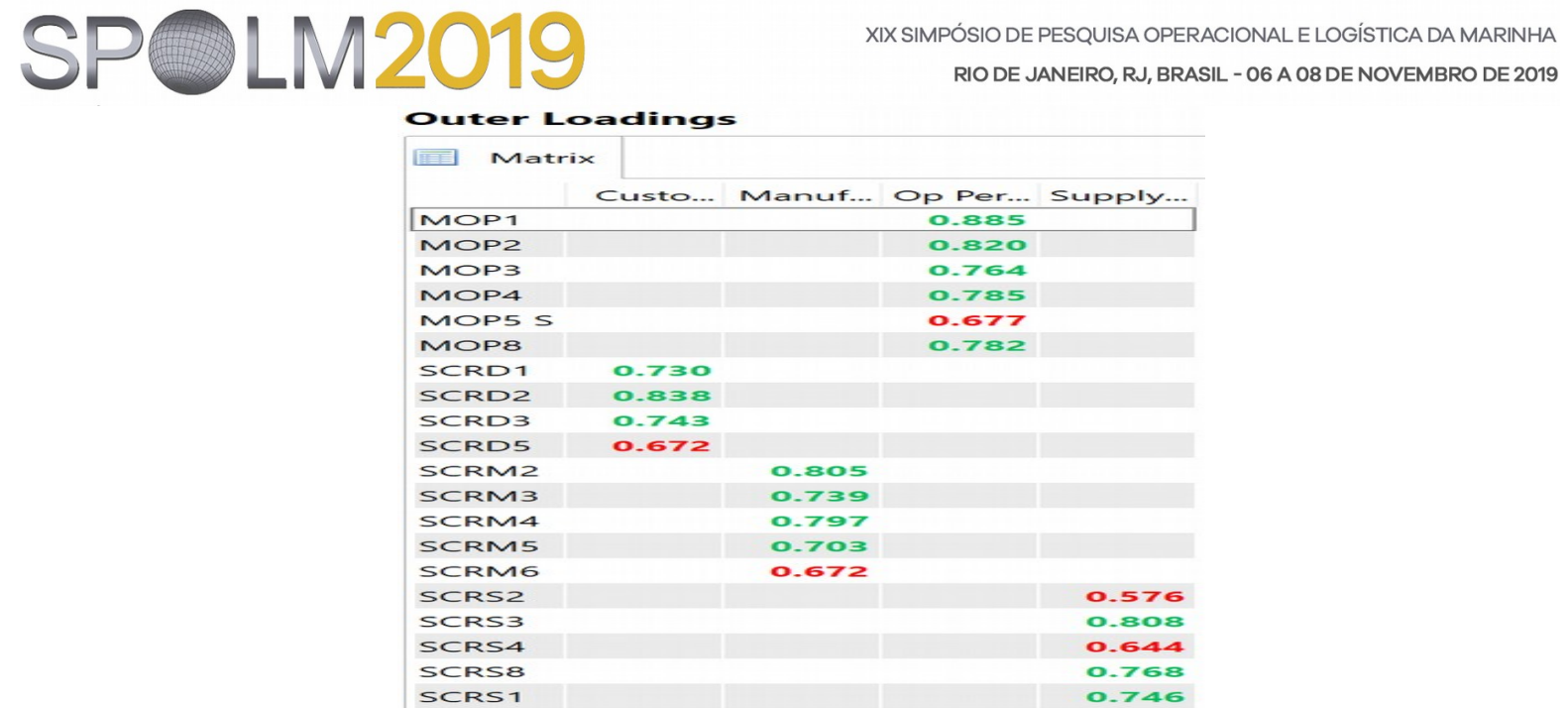

Table 5 - Outter Loadings after adjustments

Construct Reliability and Validity

\begin{tabular}{|c|c|c|c|c|c|c|c|}
\hline \multirow[t]{2}{*}{ Matrix } & fis & 接音 rho_A & 㩰望 Composite Reliability & 稆青 & Average Variance Extracted (AVE) & Copy to Clipboard: & Ex \\
\hline & $\checkmark$ & & Cronbach's Alpha & \multicolumn{2}{|r|}{ Composite Reliability } & \multicolumn{2}{|l|}{ Average Variance Extracted (AVE) } \\
\hline \multicolumn{2}{|c|}{ Supply Side Risks } & & 0.764 & .801 & 0.836 & \multicolumn{2}{|c|}{0.509} \\
\hline \multicolumn{2}{|c|}{ Op Performance } & & 0.876 & .886 & 0.907 & \multicolumn{2}{|c|}{0.621} \\
\hline \multicolumn{2}{|c|}{ Manufacturing side Risks } & & 0.799 & 0.803 & 0.861 & \multicolumn{2}{|c|}{0.555} \\
\hline \multicolumn{2}{|c|}{ Customer Side Risks } & & 0.740 & 0.767 & 0.835 & \multicolumn{2}{|c|}{0.560} \\
\hline
\end{tabular}

Table 6 - Quality Criteria (construct reliability and validity) - inner model - after adjustments

Concerning the measures available at tables 4 and 6, "Cronbach's alpha" is used to measure internal consistency reliability of the constructs whereas, as highlighted by Wong (2013), the convergent validity and discriminant validity are measures of construct validity.

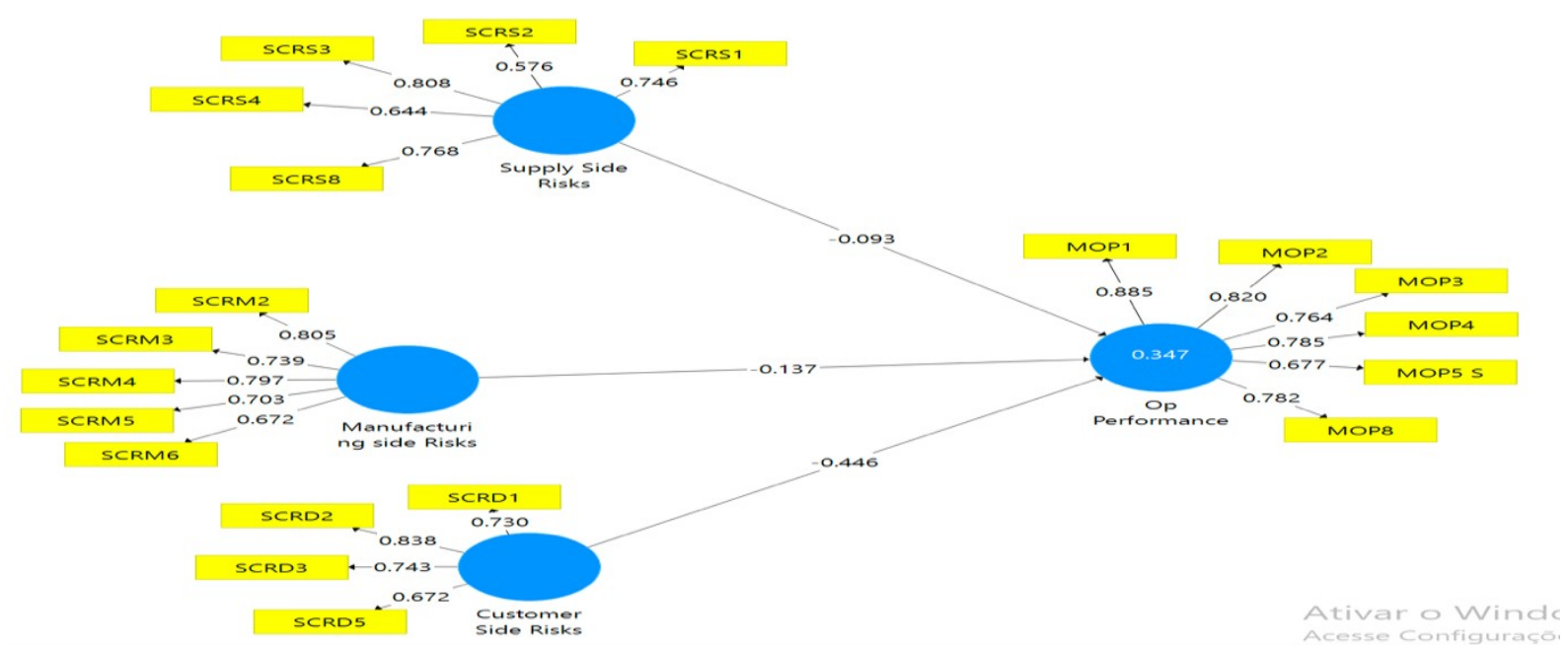

Figure 6 - Conceptual Model - (inner and outer model) after adjustments

SmartPLS can also generate T-statistics for significance testing of both the inner and outer model, using a procedure called bootstrapping. Going ahead with the statistical analysis, to obtain better statistical fit and check the statistical significance of the obtained coefficients, a structural model was estimated based on bootstrapping with 5000 subsamples as suggested by Wong (2013).

According to Wong (2013), using a two-tailed t-test with a significance level of 5\%, the path coefficient will be significant if the T-statistics is larger than 1.96. As presented in 
table 7 only the $T$-Statistics of the path Customer Side risk and Operational Performance is higher than 1.96 on our model.

\section{Path Coefficients}

\begin{tabular}{|c|c|c|c|c|c|}
\hline \multirow[t]{2}{*}{ Mean, STDEV, T-Values, P-Values } & 再 C & Confidence Intervals & 婳 & Confidence In & ias Corrected \\
\hline & \multicolumn{4}{|c|}{ T Statistics $(|\mathrm{O} / \mathrm{STDEV}|)$} & $P$ Values \\
\hline \multicolumn{4}{|l|}{ Customer Side Risks -> Op Performance } & 3.544 & 0.000 \\
\hline \multicolumn{2}{|c|}{ Manufacturing side Risks -> Op Performance } & & & 1.067 & 0.286 \\
\hline \multicolumn{3}{|l|}{ Supply Side Risks -> Op Performance } & & 0.697 & 0.486 \\
\hline
\end{tabular}

Table 7 - Checking Structural Path Significance in Bootstrapping

The multiple correlation coefficient R2, also known as the coefficient of determination, is defined as the proportion of variance explained by the regression model. Thus, its results can be seen as a measure of success of predicting the dependent variable from the independent variables (NAGELKERKE, 1991).

In the model under investigation, the coefficient of determination, R2, is 0.35 for the Operational Performance endogenous latent variable. This means that the three latent variables (SCRS, SCRM and SCRD) explain 35\% of the variance in Operational Performance.

The correlations between the latent variable and the indicators in its outer model provides to us some interesting interpretations. For instance, the main source of risks observed by Brazilian Industries, according to our sample are: "Short supplies", "Frequent delays in material supply lead-time", "Poor quality of supplies" and "Inflexibility of suppliers" (among Supply Side Risks); "High level of process variation”, "Inadequate production capability", "Variability in production cycle time", "Inflexibility in Capacity" and "Vague inspection and acceptance" (among Manufacturing Side Risks) and "Unanticipated or very volatile customer". "Large forecast error in demand", "Frequent delays in delivery to customers" and "Change in customer preference" (among Customer Side Risks).

The interpretation of the results also leads us to conclude that the relationship between Supply Side Risks and Operational Performance and Manufacturing Side Risks and Operational Performance are not statically significant and that only Customer Side Risks and Operational Performance is significant statically. Thus, only the hypothesis H3 should be considered valid, and we can assume that Customer Side Risks are negatively related with and Operational Performance.

These results suggest that when dealing with several sources of Supply Chain Risks, in the context of Brazilian Industries, "unanticipated or very volatile customer", "large forecast error in demand", "frequent delays in delivery to customers" and "change in customer preference" are the strongest factors influencing operational performance and consequently should drives the attention of Supplier Chain Managers in order to deploy actions to mitigate its occurrence.

The present investigation also contributes to the field of Contingency Theory research field. Based on the contingency model of the organization, system performance is a function of the interaction of three primary system variables: environment, resources and management. Among those, environment encompasses contextual internal and external aspects such as different sources of risks derived from suppliers and customers, and both of which are treated as independent variables in the contingency function and as so in the model of this study. 


\section{CONCLUSION}

Based on the tenets of contingency theory of the organization, where system performance is a function of the interaction of system variable set, the proposed research question of this work investigated whether Supply Side Risks, Manufacturing Side Risks and Customer Side Risks are negatively related to Operational Performance or not. For that, an empirically validated measurement models were combined and used to evaluate the impact of Supply Chain Risk upon Operational Performance.

The data collected and the results obtained in the scope of the present work added empirical evidence on Supply Chain Risks in the context of Brazilian Industries and contributed to a better understanding of the relationship between Supply Side Risks, Manufacturing Side Risks and Customer Side Risks with Operational Performance.

This research also explored the theoretical background and the main characteristics of Supply Chain Risks, which is a relatively new concept and consequently its measurement is still at an explorative stage, under development and that lack empirical observation.

After collecting data from 61 different industries, we conclude that the tested framework as whole presented statistical fit in terms of its convergent validity, internal consistency reliability, and discriminant validity.

The interpretation of the results of the T-statistics for significance testing of both the inner and outer model leads us to conclude that the relationship between Supply Side Risks and Manufacturing Side Risks with Operational Performance are not statistically relevant and that only the relationship among Customer Side Risks and Operational Performance is significant. Thus, only the proposed hypothesis 3 was considered valid and supported.

Some managerial implications emerged from the above-mentioned results. For example, when dealing with multiple risks sources, based on this study results, Supply Chain Managers may prioritize their attention and actions to mitigate the occurrence of "unanticipated or very volatile customer". "large forecast error in demand", "frequent delays in delivery to customers" and "change in customer preference" since it has an impact upon performance statistically more significant than Supply Side Risks and Manufacturing Side Risks.

Finally, it is important to state that this work has some limitations. First, this work was only related to the Brazilian business context. Secondly, it is focused solely on industrial sectors. Thirdly, the research sample did not represent the distribution of Brazilian Industries types.

Future research may be taken in a particular industrial sector and the assessment of other dimensions of Supply Chain Risks such as Logistics Side, Information Side and Environmental Side may also be considered. Furthermore, some managerial movements like supply chain integration and risk management might also be applied as moderator and mediator variables in the relationship between Supply Chain Risks and Operational Performance since contingency theory also relies on the premises that resources and management practices must be adapted to reach better performance.

\section{REFERENCES}

[1] ALORA, A.; BARUA, M. K. An integrated structural modelling and MICMAC analysis for supply chain disruption risk classification and prioritization in India. International Journal of Value Chain Management, v. 10, n. 1, p. 1-25, 2019.

[2] CHEN, H. L. Supply chain risk's impact on corporate financial performance. International Journal of Operations \& Production Management, v. 38, n. 3, p. 713-731, 2018. 
[3] EL HIRI, M.; EN-NADI, A.; CHAFI, A. Risk and Performance within Supply ChainsCase of Moroccan Industries. International Journal of Engineering Research in Africa, v. 34, p. 189-197, 2018.

[4] ENSSLIN, L.; ENSSLIN, S.R.; LACERDA, R.T.O.; TASCA, J.E. Processo de Seleção de Portfólio Bibliográfico. Processo Técnico com Patente de Registro Pendente Junto ao INPI, 2010.

[5] HARLAND, C.; BRENCHLEY, R.; WALKER, H. Risk in supply networks. Journal of Purchasing and Supply Management, v. 9, n. 2, p. 51-62, 2003.

[6] HENDRICKS, K.B.; SINGHAL, V.R. An empirical analysis of the effects of supply chain disruptions on long-run stock price performance and equity risk of the firm. Production and Operations Management, v. 14, n. 1, p. 35-52, 2005.

[7] HUO, B.; QI, Y.; WANG, Z.; ZHAO, X. The impact of supply chain integration on firm performance: The moderating role of competitive strategy. Supply Chain Management: An International Journal, v. 19, n. 4, p. 369-384, 2014.

[8] JAJJA, M. S. S.; CHATHA, K. A.; FAROOQ, S. Impact of supply chain risk on agility performance: Mediating role of supply chain integration. International Journal of Production Economics, v. 205, p. 118-138, 2018.

[9] JIN, H.Y.; FAWCETT, A.M.; FAWCETT, S.E. Awareness is not enough: commitment and performance implications of supply chain integration. International Journal of Physical Distribution \& Logistics Management, v. 43, n. 3, p. 205-230, 2013.

[10] JÜTTNER, U.; PECK, H.; CHRISTOPHER, M. Supply chain risk management: outlining an agenda for future research. International Journal of Logistics, v. 6 n. 4, p. 197-210, 2003.

[11] KNIGHT, F. H. Risk, uncertainty and profit. New York: Hart, Schaffner and Marx, 1921.

[12] KRISTENSEN, K.; ESKILDSEN, J. Design of PLS-based satisfaction studies. In: ESPOSITO, Vinzi V.; CHIN, W.; HENSELER, J.; WANG, H. (eds) Handbook of Partial Least Squares. Springer Handbooks of Computational Statistics. Berlin, Heidelberg: Springer, 2010.

[13] LATAN, H.; GHOZALI, I. Partial Least Square: Konsep, Teknik, dan Aplikasi SmartPLS 2.0 M3. Semarang: Badan Penerbit Universitas Diponogero, 2012.

[14] LAWRENCE, Paul R.; LORSCH, Jay W. Differentiation and integration in complex organizations. Administrative science quarterly, v. 12, n. 1, p. 1-47, 1967.

[15] LUTHANS, F.; STEWART, T. I. A general contingency theory of management. Academy of Management Review, v. 2, n. 2, p. 181-195, 1977.

[16] MACDONALD, J. R.; ZOBEL, C. W.; MELNYK, S. A.; GRIFFIS, S. E. Supply chain risk and resilience: theory building through structured experiments and simulation. International Journal of Production Research, v. 56. n. 12, p. 4337-4355, 2018. 
[17] MEHMET, Fatih Acar; SELIM, Zaim; MINE, Isik; FETHI Calisir. Relationships among ERP, supply chain orientation and operational performance: An analysis of structural equation modeling. Benchmarking: An International Journal, v. 24; n. 5, 2017.

[18] MILLER, K.D. A framework for integrated risk management in international business. Journal of International Business Studies, v. 23, n. 2, p. 311-31, 1992.

[19] NAGELKERKE, Nico JD. A note on a general definition of the coefficient of determination. Biometrika, v. 78, n. 3, p. 691-692, 1991.

[20] MITAL, M.; DEL GIUDICE, M.; PAPA, A. Comparing supply chain risks for multiple product categories with cognitive mapping and Analytic Hierarchy Process. Technological Forecasting and Social Change, v. 131, p. 159-170, 2018.

[21] PENNINGS, J. M. The relevance of the structural-contingency model for organizational effectiveness. Administrative Science Quarterly, p. 393-410, 1975.

[22] PUNNIYAMOORTHY, M.; THAMARAISELVAN, N.; MANIKANDAN, L. Assessment of supply chain risk: scale development and validation. Benchmarking: An International Journal, v. 20, n. 1, p. 79-105, 2013.

[23] PURDY, G. ISO 31000: 2009—setting a new standard for risk management. Risk Analysis: An International Journal, v. 30, n. 6, p. 881-886, 2010.

[24] RANGEL, D. A.; DE OLIVEIRA, T. K.; LEITE, M. S. A. Supply chain risk classification: discussion and proposal. International Journal of Production Research, v. 53, n. 22, p. 6868-6887, 2015.

[25] RAO, S.; GOLDSBY, T. J. Supply chain risks: a review and typology. The International Journal of Logistics Management, v. 20, n. 1, p. 97-123, 2009.

[26] RUDOLF, C. A.; SPINLER, S. Key risks in the supply chain of large scale engineering and construction projects. Supply Chain Management: An International Journal, v. 23, n. 4, p. 336-350, 2018.

[27] SHOU, Y.; HU, W.; KANG, M.; LI, Y.; PARK, Y. W. Risk management and firm performance: the moderating role of supplier integration. Industrial Management \& Data Systems, v. 118, n. 7, p. 1327-1344, 2018.

[28] SITKIN, S. B.; PABLO, A. L. Reconceptualizing the determinants of risk behavior. Academy of management review, v. 17, n. 1, p. 9-38, 1992.

[29] RUNGTUSANATHAM, M. J. et al. Survey research in operations management: historical analyses. Journal of Operations management, v. 21, n. 4, p. 475-488, 2003.

[30] SWEENEY, E.; GRANT, D., MANGAN, J.J; WAGNER, B. The implementation of supply chain management theory in practice: an empirical investigation. Supply Chain Management: An International Journal, v. 20, n. 1, p. 56-70, 2015.

[31] TANG, O.; MUSA, S. N. Identifying Risk Issues and Research Advancements in Supply Chain Risk Management. International Journal of Production Economics, v. 133, p. 25-34, 2011. 
[32] VOSS, Christopher A.; ÅHLSTRÖM, Pär; BLACKMON, Kate. Benchmarking and operational performance: some empirical results. International Journal of Operations \& Production Management, v. 17, n. 10, p. 1046-1058, 1997.

[33] WAGNER, S. M.; BODE, C. An empirical investigation into supply chain vulnerability. Journal of purchasing and supply management, v. 12, n. 6, p. 301-312, 2006.

[34] WONG, K. K. K. Partial least squares structural equation modeling (PLS-SEM) techniques using SmartPLS. Marketing Bulletin, v. 24, n. 1, p. 1-32, 2013.

[35] ZHAO, L.; HUO, B.; SUN, L.; ZHAO, X. The impact of supply chain risk on supply chain integration and company performance: a global investigation. Supply Chain Management: An International Journal, 18(2), 115-131, 2013.

[36] ZSIDISIN, G. A.; PANELLI, A.; UPTON, R. Purchasing organization involvement in risk assessments, contingency plans, and risk management: an exploratory study. Supply Chain Management: an international journal, v. 5, n. 4, p. 187-198, 2000.

\section{APPENDIX A - SUPPLY CHAIN RISKS MEASURES}

Instructions:

- Questions regarding Risk Measures start with the letters "SCR";

- Read each source of risk and its respective variable carefully;

- Rate a grade for each risk variable by considering to what extent your company / organization in recent years has had a negative impact because of the variable presented. Use the 5-point scale for "high occurrence" and 1 point when "not observed".

(Please put in the relevant box based on your rating for each risk variable. Please assign only one rating for each risk variable)

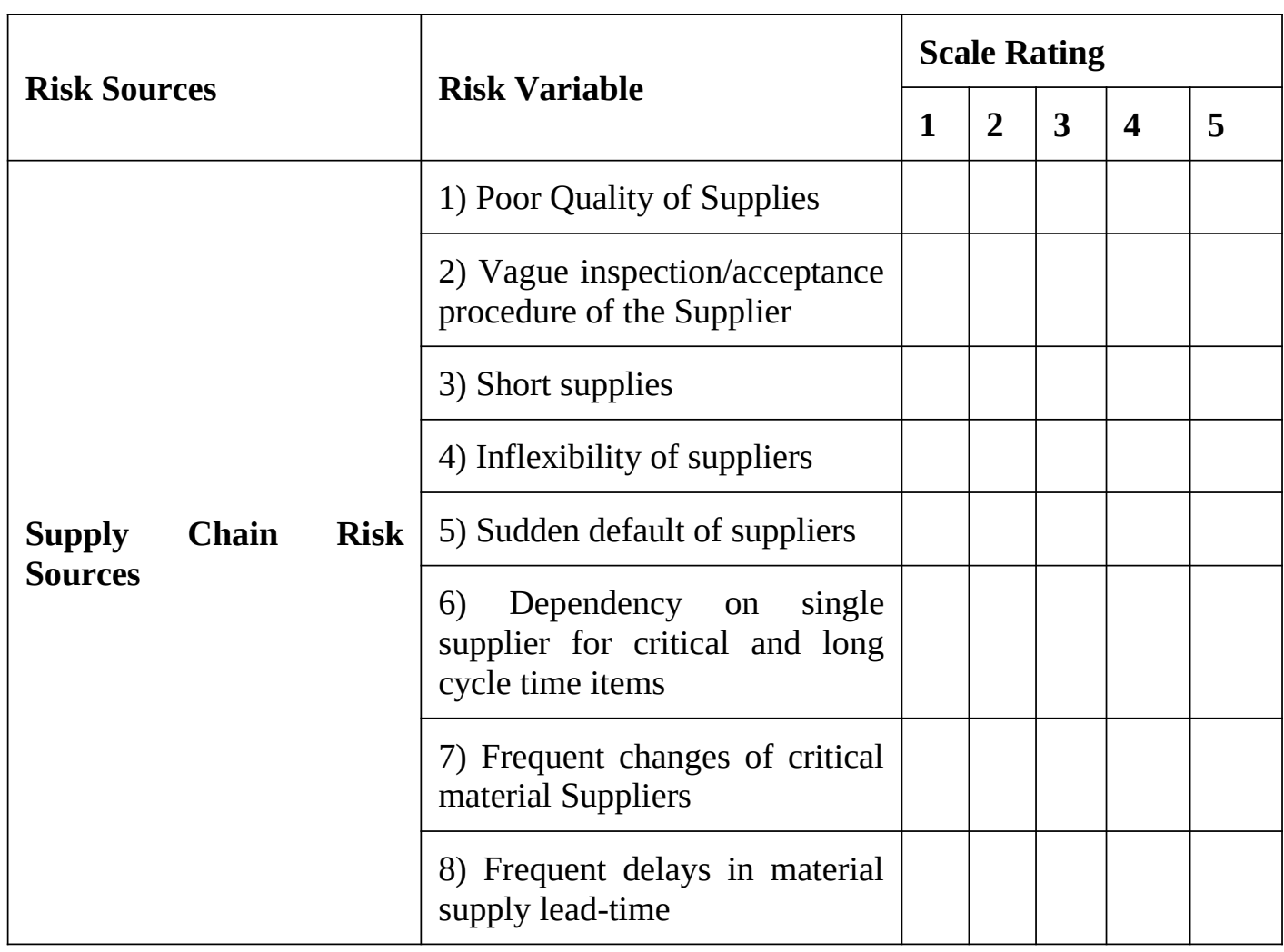




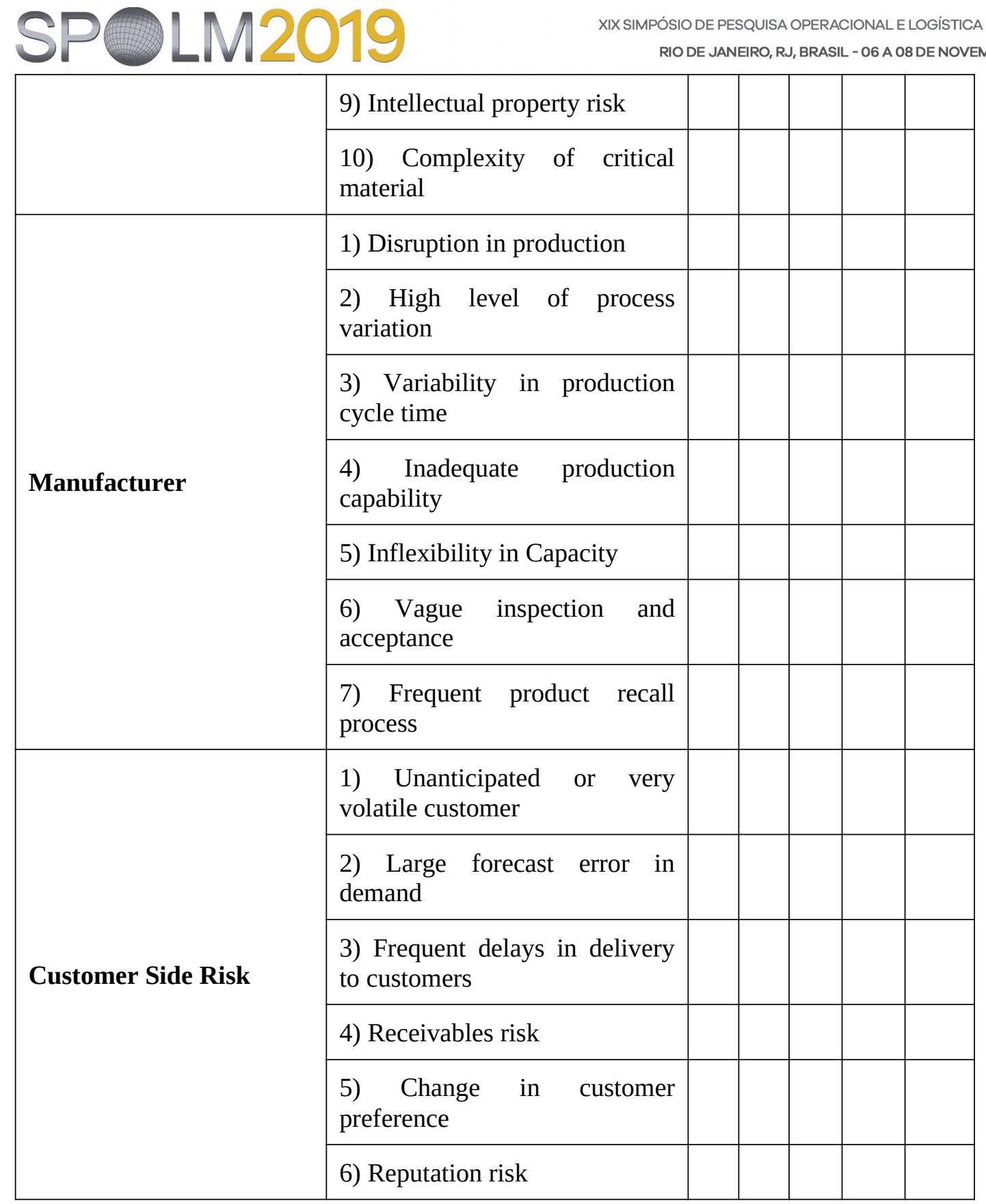

Table 1 - Adapted from Punniyamoorthy et al (2013).

\section{APPENDIX B: OPERATIONAL PERFORMANCE MEASURES}

Instructions:

- Questions regarding Operational Performance Measures start with the letters "MOP"

- Indicate your evaluation for each variable according to the performance of your company / organization in the market. Assign only one rating for each dimension, being: 1-Very Poor; 2Below Average; 3-Average; 4-Above Average and 5-Excellent

\begin{tabular}{|c|l|l|l|l|l|}
\hline Operational Performance Variable & $\mathbf{1}$ & $\mathbf{2}$ & $\mathbf{3}$ & $\mathbf{4}$ & $\mathbf{5}$ \\
\hline Delivery on time & & & & & \\
\hline Order fulfilment & & & & & \\
\hline Forecasting accuracy & & & & & \\
\hline Lead time & & & & & \\
\hline
\end{tabular}




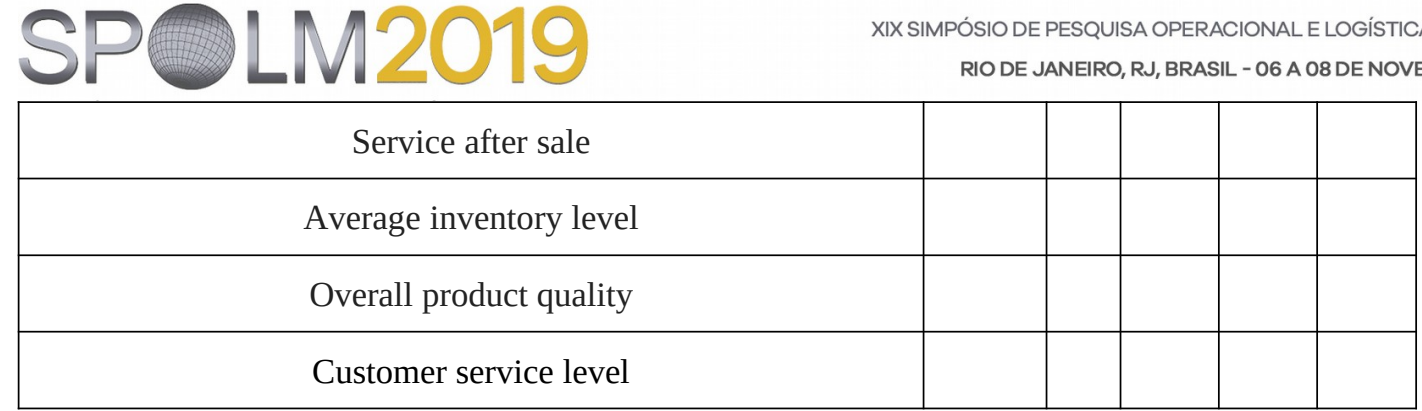

Table 2 - Adapted from Huo, et al 2014); Bongsug et al (2014); and Mehmet et al (2017) 